\title{
$\mathrm{ACQ}$ 약제의 목재 내 침투 및 부후 특성에 미치는 목재 조직의 영향*1
}

이 현 미*2 • 이 동 흡*2 - 황 원 중*2†

\section{Penetration of ACQ Treatment and its Effect of Degradation on Wood Tissues (Structure)*1}

\author{
Hyun-Mi Lee*2 Dong-Heub Lee*2 . Won-Joung Hwang*2†
}

\section{요 약}

구리계 보존제 처리에 대한 기초 자료를 얻기 위하여 Douglas fir 변재와 ACQ-2 보존제를 사용하여 목재 내 침투 및 부후 특성을 조사하였다. 약제의 주입이 어려운 Douglas fir 수종에 대하여 약제의 주입이 잘된 곳과 안된 곳의 시료를 채취하여 약제 이동을 방해하는 인자를 구명하고자 방사조직 높이, 방사조직 밀도, 가도관의 길이를 실체현미경, 광학현미경, 그리고 전자현미경으로 측정 및 관찰하였다. 그 결과 방사조직의 높이와 밀도 그리고 가도관길이는 약제의 주입이 용이했던 부분과 주입이 안된 부분에서 차이를 보이지 않았지만, 목재 구성 세포들의 벽공에서는 차이가 나타났음을 전자현미경을 통해 관찰할 수 있었다. 약제의 주입이 안된 곳에서는 폐 색된 벽공이 많이 관찰되었다. 그리고 여러 농도의 $\mathrm{ACQ}$ 로 처리한 목재 시편을 갈색부후균으로 부후시킨 후 광학 현미경으로 부후 특성을 관찰하였다. 그 결과 무처리 시편의 가도관, 방사조직, 수지구 등의 조직이 부후되어 파괴된 것을 볼 수 있었으며, 약제 처리 농도가 낮으면 부후가 진행되므로 일정 농도 이상으로 처리해야함을 알 수 있었다.

\section{ABSTRACT}

To obtain the basic information on wood preservative process using copper, the penetration ACQ-2 preservative agent into Douglas fir wood and its degradational characteristics were investigated. Douglas fir is known to be difficult for preservative agent injection. To find the hindrance factor of the preservatives movement, the ray height, ray density, and length of tracheid

\footnotetext{
*1 접수 2013년 10월 15일, 채택 2013년 11월 22일

*2 Department of Forest Products, Korea Forest Research Institute, Seoul 130-712, Korea

† 교신저자(corresponding author) : 황원중(e-mail: wonjoung@forest.go.kr)
} 
were measured and observed by a stereoscopic microscope and scanning electron microscope. The results were compared in the well-penetrated parts of preservatives and insufficient parts. There were no significant differences in height, length, and density between both parts, except for the pits of the wood elements observed in SEM micrograph. More declosed pits were found in the well-penetrated parts of preservatives.

Decay characteristics of wood specimen treated with various ACQ concentrations by brown-rot fungi was observed by an optical microscope. The decayed properties of tracheid, rays, and resin canals was found in the non-treated wood specimens and it was also found that some extent of preservatives concentration is necessary to protect the decay.

Keywords: ACQ preservative, Douglas fir, decay characteristics, ray height, tracheid

\section{1. 서 론}

목재를 구성하는 세포는 수종 고유의 유전인자, 환경에 따른 구성요소의 크기, 형태, 배열 등이 다양 하게 변화하며, 특히 침엽수에 비해 구성요소가 복 잡한 활엽수에서 변이가 심하다(박, 1981). 침엽수 재의 방사조직은 형성층에 존재하는 방사조직 시원 세포에서 분열되어 형성된 조직으로서 수간 내에서 방사방향으로 배열되어 있어 수목의 방사방향으로 수분 또는 양분을 이동시키거나 저장하는 능력을 가 진 세포이다. 이러한 침엽수재의 방사조직은 구성비 율이 수종에 따라 많은 차이가 있으나 보통 4 7\% 정도이며 목재의 물리적 성질과 기계적 성질에 많은 영향을 미치고 있다(이, 1987). 침엽수재 가도관은 뿌리에서 잎까지 수분통도 및 기본구조를 지지하는 역할을 하고 있다(Romberger et al., 1993; Barnett, 2004). 목재 내 평균 가도관 길이는 보통 $1 \sim 5 \mathrm{~mm}$ 정도이다(Helander, 1933; Atmer and Thörnqvist, 1982; Molteberg and Høibø, 2006). 가도관 길이는 줄기에 따라 방사, 접선단면과 관련이 있으며 뿐만 아니라 나무의 생장속도와도 관련이 있다(Bailey and shepard, 1915). 가도관의 지름, 벽후 및 길이 는 수종 간은 물론 동일 수종 내에서도 생장의 양부, 수체 내의 부위 등에 따라 복잡하게 변화되며, 특히 길이의 변화가 현저하다(박상진 외, 1987). 일반적 으로 방사조직의 높이가 증가함에 따라 단위면적당 방사조직의 수와 밀도는 점차 감소되는 경향이 있
고, 방사조직의 밀도가 커짐에 따라 방사조직의 폭 은 증가하는 경향이 있다(이, 1987). 그리고 나무의 밀도는 사용 가능한 물질의 양을 측정하진 않지만, 그 세포의 구조나 조직에 대한 정보를 포함하고 있 다(Rathgeber et al., 2006).

이상과 같이 목재의 구성 세포들은 물질의 이동에 중요한 역할을 담당하고 있다. 따라서 수용성 방부 제를 목재 내에 주입하여 방부효력을 나타나게 하기 위해서는 목재 구성 세포들이 방부약제의 침투에 어 떻게 기여하고 관여하는지를 아는 것은 매우 중요하 다고 할 수 있다. 또한 수용성 방부제는 토양에 접하 거나 야외에 사용되었을 때에는 빗물이나 수분에 의 해 방부제의 주요 성분이 목재로부터 빠져나오기 때 문에 목재내에 어느 정도의 약제를 주입했을 때 충 분한 방부효력을 발휘하는가에 대해서도 생각해야 한다.

따라서 본 연구에서는 방부처리 시 구리계 목재보 존제 $(\mathrm{ACQ})$ 의 목재 내 침투 시 관여하는 목재구성세 포의 역할을 조사하였고, 약제의 주입량에 따른 목 재의 부후 특성을 현미경을 통해 관찰하였다.

\section{2. 재료 및 방법}

\section{1. 공시재료}

본 실험에서는 소나무(Pinus densiflora S. et Z.) 변재와 미송(Douglas fir)을 공시재료로 이용하였고 
ACQ-2 (Alkaline Copper Quaternary; 유효농도 $14.5 \%)$ 보존제를 사용하였다. 공시균은 갈색부후균으 로 Fomitopsis palustris (FRI 21055)를 사용하였다.

\section{2. 약제 처리}

구리계 보존처리목재에 대한 실내 방부 효력을 조 사하기 위하여 소나무와 미송 변재 $(20 \times 20 \times 10$ $\mathrm{mm}$ )를 사용하였다. ACQ-2 약제는 무처리, 0.15 , $0.25,0.45,0.85,1.25 \%$ 로 유효농도를 조절하여 감 압 및 가압주입처리를 실시하였다. 약제가 주입된 목재시표는 실내에 3 주간 보관 후 내후조작을 실시 하였다. 내후조작은 $25^{\circ} \mathrm{C}$ 물에 8 시간 교반하는 용탈 과정과 용탈조작을 끝낸 시험체는 $60^{\circ} \mathrm{C}$ 에서 16 시간 건조보존하며 휘산 시키고, 전체적으로 10 회 반복하 였다.

\section{3. 약제의 침투 특성 관찰}

방부약제의 목재 내 침투에 있어서, 활엽수의 경 우는 도관에서 그리고 침엽수의 경우에는 가도관에 서 가장 많은 약액이 침투한다. 그 이유는 도관과 가 도관은 물이 이동하는 통로 역할을 하기 때문이다. 또한, 방사조직은 수간의 수평방향으로의 물질 이동 에 관여하고 있으므로 수용성 방부제의 이동에 방사 조직이 어느 정도 관여하는지를 조사하였다. 방사조 직의 높이와 밀도는 김(2009a)이 측정한 방법으로 측정하였다. 약제의 침투 특성 관찰에는 실체현미경 (Cral Zeiss, Stemi 2000C)과 전자현미경(SEM, S$3500 \mathrm{~N}$, Hitachi)을 이용하였다.

\section{4. 부후 시험 및 부후 특성 관찰}

방부효력 시험은 내후조작이 끝난 시료를 사용하 였으며, KS M 1701, 부속서 2 목재 방부제의 방부 효력 시험 방법에 준하였다.

ACQ-2 처리목재는 배양기 전면에 퍼진 공시균 위 에 멸균해 둔 시험체를 올린 후 온도 $26 \pm 2^{\circ} \mathrm{C}$, 상대 습도 $70 \%$ 이상인 곳에서 12 주 동안 폭로하였다. 12
Table 1. Anatomical characteristics of ACQ treated Douglas-fir wood.

\begin{tabular}{|c|c|c|}
\hline & $\begin{array}{c}\text { Excellent } \\
\text { preservative } \\
\text { injection }\end{array}$ & $\begin{array}{l}\text { Low preservative } \\
\text { injection }\end{array}$ \\
\hline $\begin{array}{l}\text { Length of } \\
\text { tracheid }(\mathrm{mm})\end{array}$ & $3.44 \pm 0.40$ & $3.10 \pm 0.32$ \\
\hline $\begin{array}{c}\text { Ray height } \\
\text { (Cell number) }\end{array}$ & $3.66 \pm 1.42$ & $3.86 \pm 1.37$ \\
\hline $\begin{array}{l}\text { Ray density } \\
\left(\text { No. } / \mathrm{mm}^{2}\right)\end{array}$ & $24.73 \pm 1.60$ & $25.40 \pm 1.50$ \\
\hline
\end{tabular}

주 경과 후 시험체를 꺼내어 표면의 균사 그 외의 부 착물을 충분히 제거한 후 $60^{\circ} \mathrm{C}$ 에서 48 시간 건조하 였다. 그리고 부후 특성을 조사하기 위하여 광학현 미경(Carl Zeiss, Axio Imager M2)을 이용하여 관찰 하였다(Fig 3).

\section{3. 결과 및 고찰}

\section{1. 약제의 침투 특성}

\subsection{1. 목재 구성세포의 역할}

약제 주입이 어려운 Douglas fir 수종에 대하여 약 제의 주입이 잘된 곳과 안된 곳을 관찰함으로서 약 제 이동을 방해하는 인자를 구명하고자 방사조직 높 이, 방사조직 밀도, 가도관의 길이를 측정하여 Table 1에 나타냈다. Table 1에서 보여주었듯이 약 제의 주입이 잘된 부분과 안되는 부분에서 방사조직 의 높이와 밀도, 가도관 길이의 차이는 보여지지 않 았다. 이러한 결과로부터 본 실험에 사용된 공시재 료는 방사조직과 가도관의 크기에 영향을 받지 않는 것으로 생각된다.

일반적으로 침엽수재의 가도관은 수에서 수피 방 향으로 갈수록 연륜 증가와 함께 길이가 증가하다가 일정 연륜에서 최대치에 다다른 후 거의 일정해지는 경향을 보여주고 있다. Ingrid de Kort (1990)는 Douglas fir의 가도관 길이는 일반적인 침엽수 가도 관 길이 변화를 보여주고 있으며, 성숙재 부분에서 


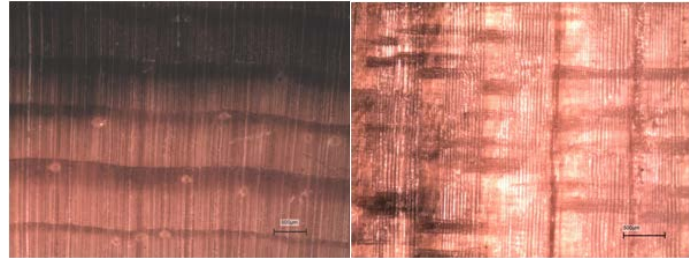

Fig. 1. The interface of the well-penetrated parts of preservatives and insufficient parts on cross section and radial section. Scale bars $=500 \mu \mathrm{m}$.

약 3.6 4.2 mm 정도로 보고하였다. 이 결과를 참고 하면 본 실험에서 사용한 판재가 성숙재 부분임을 알 수 있다. 그리고 같은 난주입수종의 하나인 일본 잎갈나무의 가도관 길이는 $772 \sim 5,272 \mu \mathrm{m}$ (이, $1985)$ 정도로 보고되며, 일반적으로 침엽수 중에서 약제의 침투가 용이한 소나무의 경우, 가도관 길이 는 1,600 2,700 $\mu \mathrm{m}$ (이, 1985)와 3.15 3.26 mm (Kim과 Mishiro, 1998)로 보고되고 있다. 따라서 가 도관 길이는 약제의 침투에 영향을 주기보다는 수종 간의 차이로 보는 것이 더 타당할 것으로 생각된다. 그리고 가도관이 액체의 이동에 관여하는 요인으로 생각할 수 있는 것은 목재 내 추출물의 영향을 생각 할 수 있다. 즉, 변재의 가도관에서는 물의 흐름이 원활하지만 심재의 가도관에서는 추출물 등이 벽공 이나 내강에 존재하며 액체의 흐름을 방해 하거나 느리게 하는 현상을 생각할 수 있다.

방사방향으로의 물질 이동은 방사조직이 담당하 고 있기 때문에 약제의 이동에 크게 관여할 것으로 생각하였으나, 약제 주입이 안된 곳과 주입이 잘된 곳의 차이는 나타나지 않았다(Table 1). 이러한 결 과는 하나의 목재 내에서 약제의 이동 유무, 또는 이 동의 차이에 방사조직이 크게 관여하지 않는 것으로 생각할 수 있다. 방사조직의 차이가 약제 이동의 차 이에 직접 관여하지 않는다고 생각할 수 있는 또 다 른 이유는 약제의 주입성이 다른 잣나무와 일본잎갈 나무의 방사조직 변이의 경우에서도 찾을 수 있다 (이, 1990; 김, 2009a, 2009b). 즉, 방사조직이 약제 의 주입성에 크게 관여한다고 가정하면 약제의 주입 성이 일본잎갈나무에 비해 좋은 잣나무에서 방사조

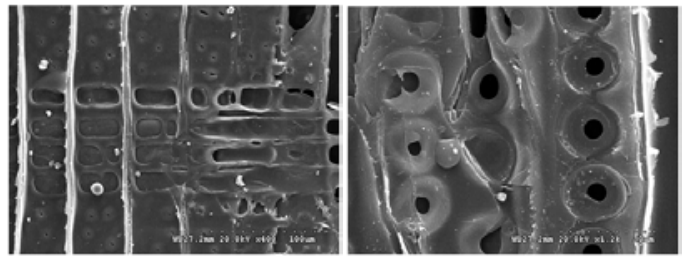

Fig. 2. SEM photographs of the well-penetrated parts of preservatives. Scale bars $=100 \mu \mathrm{m}, 30 \mu \mathrm{m}$.

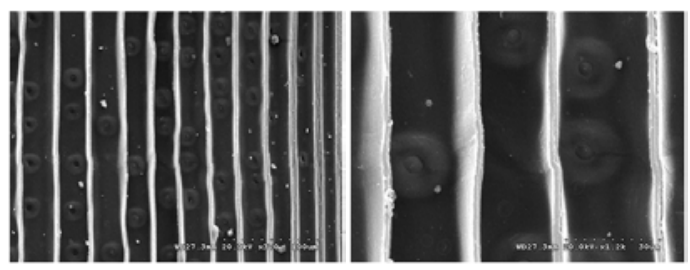

Fig. 3. SEM photographs of the insufficiently penetrated part of preservatives. Scale bars $=100 \mu \mathrm{m}, 30 \mu \mathrm{m}$.

직의 높이와 밀도가 높아야 하지만, 이전의 보고 (이, 1990; 김, 2009a, 2009b)에 의하면 반대의 결과 들이 보고되었기 때문이다.

Fig. 1은 약제 주입후 약제 주입이 잘된 부분과 안 된 부분의 경계를 중심으로 횡단면과 방사단면에서 실체 현미경으로 관찰한 것이다. 그림에서도 약제의 주입에 따른 변화를 명확히 알 수 있을 정도로 경계 가 뚜렷하였다. 이 경계를 중심으로 가도관 길이, 방 사조직 높이와 밀도를 측정한 결과(Table 1) 약제 이동에 방해가 될만한 요소의 차이는 발견하지 못하 였다. 따라서 물질 이동에 관여하고 있는 또 다른 요 소인 벽공을 주사전자현미경으로 관찰하였다(Figs. 2 and 3$)$.

그 결과 Figs. 2와 3에서도 알 수 있듯이 경계를 중심으로 폐색된 벽공의 차이가 명확하게 나타났다. 따라서, 한 수종 내에서 약제의 주입 및 분포에 가장 크게 영향을 미치는 것은 벽공의 형태인 것으로 생 각되어졌다. 폐색된 벽공이 수분이동을 방해하는 것 은 Shusheng 등(1994)도 보고한 바 있다. 한편 유연 벽공이 열리거나 닫히는 것에 대해서는 목재의 생장 

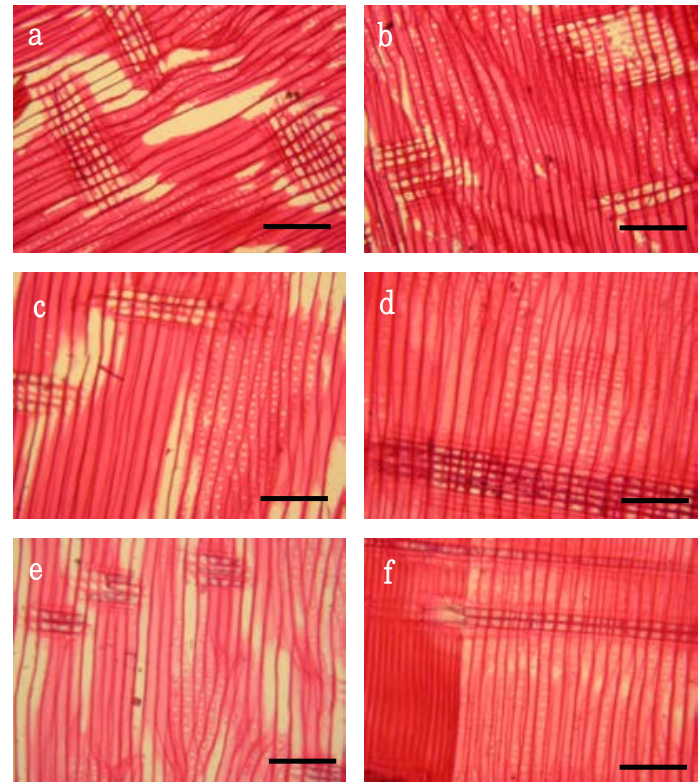

Fig. 4. Optical micrographs of radial sections of non-treated (a) and ACQ treated samples that were decayed by brownrot fungi, $0.15 \%$ (b), $0.25 \%$ (c), $0.45 \%$ (d), $0.85 \%$ (e) and $1.25 \%$ (f). Scale bars $=100 \mu \mathrm{m}$.

과정에서 발생하기도 하고, 건조과정에서도 발생한 다(Fujii 등, 1997)고 알려져 있다.

\section{2. 갈색부후균에 의한 거시적 부후 특성}

Figs. 4와 5는 ACQ-2로 처리한 6가지 농도와 무 처리재 시편을 갈색부후균에 12 주간 노출시킨 후의 광학현미경 사진이다. Figs. 4와 5에서 볼 수 있듯이 목재 조직의 파괴 형상은 처리 농도가 낮을수록 심 하게 나타났음을 알 수 있었다.

약제를 처리하지 않은 무처리재의 부후 특징은 광 학현미경과 전자현미경을 이용한 많은 연구가 이루 어져 왔다. 갈색부후균은 세포내강으로 처음에 침투 하여 목재의 셀룰로오스 성분을 주로 파괴한다. 그 후 벽공, 세포벽의 간극을 통하여 성장하면서 다른 세포벽까지 파괴한다(신 과 안, 1996). 침엽수재의 부후는 균사가 자란 대부분의 목재내강에 있는 $\mathrm{S} 3$
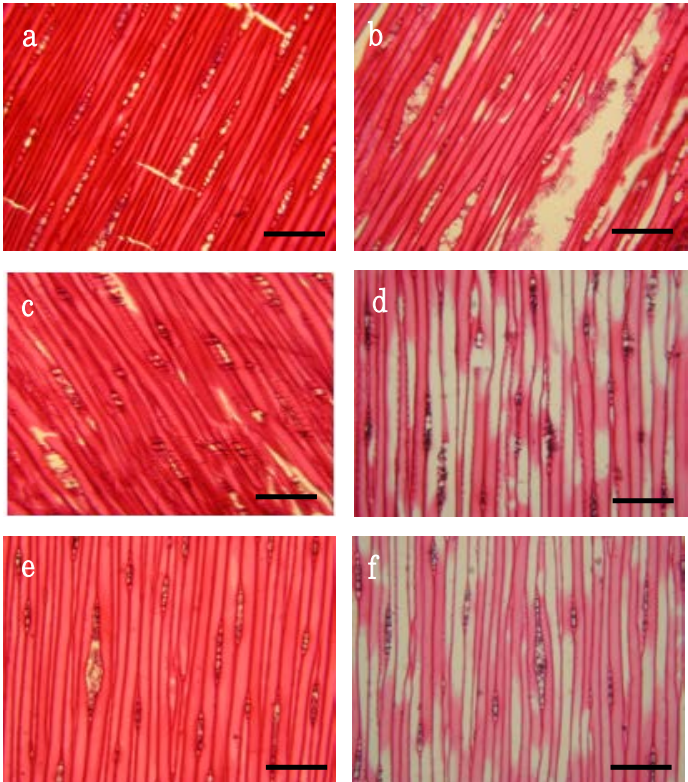

Fig. 5. Optical micrographs of tangential sections of non-treated (a) and ACQ treated samples that were decayed by brown-rot fungi, $0.15 \%$ (b), $0.25 \%$ (c), $0.45 \%(d), 0.85 \%(e)$ and $1.25 \%(f)$. Scale bars $=100 \mu \mathrm{m}$. Scale bars $=100 \mu \mathrm{m}$.

층의 표면에서 볼 수 있으며(Schwarze, 2007), 본 실험의 시험편에서도 관찰되었다.

\subsection{1. 방사단면상의 특징}

방사가도관에는 거치상비후부의 돌기가 뚜렷하 여, 방사유세포의 수평벽은 얇고, 직교분야벽공은 창상형이다. Fig. 4의 방사단면에서 관찰된 갈색부 후균에 의해 부후된 무처리재의 특징은 방사유세포 가 대부분 열화 되고 있었다. 그리고 약제 처리 농도 가 높을수록 목재조직의 식별이 명확하게 나타났다.

\subsection{2. 접선단면상의 특징}

Fig. 5는 무처리재와 여러 농도로 처리한 약제처 리재의 접선단면 현미경 사진이다. Fig. 5 에서 관찰 된 갈색부후균에 부후된 공시재료의 현미경적 특징 은 무처리와 농도가 낮은 $0.15 \%, 0.25 \%, 0.45 \%$ 의 
에피델리얼 세포와 단열방사조직의 파괴가 심하게 나타났음을 알 수 있다. 그리고 약제 농도가 높은 $1.25 \%$ 에서는 유연벽공과 에피델리얼 세포의 식별 이 명확하게 될 만큼 부후균에 의해 피해를 받지 않 은 것을 알 수 있다.

\section{4. 결 론}

생물열화인자들로부터 목재를 보호하고 장기간 사 용하기 위한 방법으로서 널리 사용되고 있는 방부 약 제 주입처리에서 중요한 약제의 목재 내 침투 인자를 목재 구성세포 단위에서 그 역할을 조사하였고, 방부 약제 처리 후 부후 특성에 대하여 조사하였다.

그 결과 하나의 목재 내에서 목재보존제 (ACQ-2) 의 목재 내 침투 시 관여하는 구성세포 인자들은 가 도관길이, 방사조직의 높이 및 밀도 보다는 벽공의 형태가 가장 크게 영향을 주는 것으로 나타났다.

$\mathrm{ACQ}$ 처리재의 부후 특성에서는 무처리재에서 가 장 심한 세포벽 파괴현상을 보여주었으며, 균사가 세포내강으로 1 차 침입한 후 벽공과 세포벽을 파괴 하는 것으로 나타났다. 약제 처리재는 주입처리 농 도가 낮을수록 심하게 나타났음을 알 수 있었다. 또 한 일정 농도 이상 처리부터는 부후균에 대한 저항 성이 크게 나타났다.

\section{참 고 문 헌}

1. 김남훈. $2009 \mathrm{a}$. 잣나무와 낙엽송재 방사조직의 연륜 내 및 축방향 변이성. 목재공학 37(1): 65 72.

2. 김남훈. $2009 \mathrm{~b}$. 잣나무재와 일본잎갈나무재의 방사방 향 방사조직 밀도 및 연륜 내복열방사조직 출현 빈도 수 변이. 목재공학 37(6): 531 536.

3. 박상진. 1981. 환공재 주요 구성요소의 방사방향 변동. 목재공학 9(3): 1 6.

4. 박상진, 이원용, 이필우. 1987. 제5장 침엽수재의 조직. 목재조직 및 식별. p. 99.

5. 신동소, 안세희. 1996. 목재보존학. pp. 52 55.

6. 이소미, 김병로. 2005. 일본잎갈나무 수 간내 재질 변동 에 관한 연구(II) - 가도관 길이와 폭, 마이크로피브릴 경각, 강도의 남북방향의 변동 - 목재공학 33(1): 21 28.

7. 이원용. 1987. 침엽수재의 방사조직에 관한 연구. 목재 공학 15(2): 90 98.
8. 이원용. 1990. 북양 주요 침엽수재의 가도관장과 방사 조직의 변이. 임산과학연보 7: 1 6.

9. 이필우. 1985. 목재해부학.

10. Atmer, B., and T. Thörnqvist. 1982. The properties of tracheids in spruce (Picea abies Karst.) and pine (Pinus sylvestris L.). The Swedish university of agricultural sciences, department of forest products. Reports No. 134. 59p. (in Swedish with English summary).

11. Bailey, I. W., and H. B. Shepard. 1915. Sanio's laws for the variation in size of coniferous tracheids. Bot. Gaz. 60(1): 66 71.

12. Barnett, J. R. 2004. Xylem physiology. In: Burley, J., Evans, J. \& Youngquist, J. A. (eds). Encyclopedia of forest Sciences. Elsevier Academic press, Oxford, San Diego, California, p. 1583 1590.

13. Dinwoodie, J. M. 1961. Tracheid and fibre length in timber. A review of literature. Foresty 34: 125 144.

14. De Kort, I. 1990. Tracheid length in vital Douglas fir (Pseudotsuga Menziesii) in the netherlands. 11(2): 203 209.

15. Fuju, T., Y. Suzuki and N. Kuroda, 1997. Bordered pit aspiration in the wood of Cryptomeria Japonica in relation to air permeability. 18(1): 69 76.

16. Helander, A. B. 1933. Variations in tracheid length of pine and spruce. Foundation for forest research of Finland. No. 14. 75p. (in Finnish with English Summary).

17. Kim, B. R. and A. Mishiro. 1998. Studies on variability of wood properties in stem of Pinus koraiensis (II) - Differences in tracheid length, microfibril angle and compressive strength on the south and north sides of stem -. Journal of Wood Science 1(1): 46 51.

18. Molteberg, D. and O. Høibø. 2006. Development and variation of wood density, kraft pulp yield and fibre dimensions in young Norway spruce (Picea avies). Wood Science \& Technology 40: 173 189.

19. Romberger, J. A., Z. Hejnowicz, and J. F. Hill. 1993. Plant structure: Function and development. Springer-Verlag, Barlin-Heidelberg-New York. 524p.

20. Rathgeber, C. B. K., V. Decoux, and J. Leban. 2006. Linking intra-tree-ring wood density variations and tracheid anatomical characteristics in Douglas 
fir (Pseudotsuga menziesii (Mirb.) Franco). Annals of forest Science 63: 699 706.

21. Shusheng, P., T. A. G. Langriah, and R. B. Keey. 1994. Moisture mobement in softwood timber at elevated temperatures. Drying Technology: An international Journal 12(8): 1897 1914.
22. Smith, D. M. 1965. Rapid measurement of tracheid cross-sectional dimensions conifers. Forest Products Journal 15: 325 334.

23. Zabel, R. A. and J. J. Morrell. 1992. Wood microbial decay and its preservatives. Academic Press. San Diago. pp: 476. 